\title{
Acceptable Block Beef from Steers Grazing Range and Crop Forages
}

\author{
C. WAYNE COOK, DAVID A. CRAMER, AND LARRY RITTENHOUSE
}

\begin{abstract}
Steers from 3 frame sizes were raised from birth to slaughter under different feed regimens including raised on the range to 18 months of age, raised on the range along with complementary forages to 18 months of age, and raised on the range to 18 months of age with subsequent concentrate feeding for 66 days. Quality grade, marbling, rib-eye area, fat thickness, and intramuscular fat were significantly higher for grain fed animals than for the grazing animals. There were no significant differences in uverall palatability traits for grazing steers and grain fed steers. Small-frame steers gained less per day but had higher finish at comparable ages and period of treatment than large-frame steers. Acceptable primal cuts can be produced from grazing alone but the quality grade is higher for grain-fed animals. It was concluded that future beef production may use far more range and forage because of higher grain prices and an increasing demand for leaner meat by the consumer.
\end{abstract}

The costs of grains for domestic livestock feeding and the price for beef at the marketplace will determine the future production systems that are profitable. As a result of relative-cost inputs, such systems will no doubt include larger quantities of pasturage and forages and less grain. These systems include finishing animals on grazed range and/or forages, supplementing on grazed forages with grain, or growing animals on grazed forages followed by finishing in the drylots. This latter alternative can be accomplished by feeding shorter periods of time on high grain rations or feeding a longer time on high roughage rations.

Süch changes in finishing practices are causing packers and merchandizers to question the quality and acceptance of beef produced under these new forage systems. As a result, research has not had an opportunity to investigate all of the ramifications of forage finished carcasses. Which breeds or biological types of cattle are best suited to such feeding regimens are still unknown. What factors influence consumer acceptance of such meats are still

\footnotetext{
Authors are with the Departments of Range Science and Animal Science, Colorado State University, Fort Collins 80523.

This report is Scientific Series Paper No. 2844 published with the approval of the Directó of Colorado Agricultural Experiment Station.

Manuscript received February 8, 1983.
}

somewhat vague. Also of importance is that current research may reveal new tenderization methods along with longer chilling treatments that will enhance the palatability traits of lower grades of beef.

In addition to changes in beef production systems being dictated by fluctuating grain prices, the consumer appears to be seeking a leaner piece of beef than was formerly found in the marketplace. As a result, purvcyors and retailers are attempting to select beef with a minimum fleshiness or finish that is acceptable to consumers. Too little fat may reduce eating quality of beef but too much fat is expensive to produce and reduces the percent of saleable meat because of trimming. A covering of subcutaneous fat appears to extend the chilling period with an insulating action which makes the meat more tender and flavorful. Bowling et al. (1981) suggests that if this is indeed the case, time in the feedlot could be greatly reduced by using alternative chilling methods which would lower production costs as well as the amount of fat on the carcass.

All of these situations favor increased slaughter of pasturefinished cattle, cattle fed on high roughage rations or on high grain rations for only short periods. The alternative systems will differ by region because of environment and the resultant availability of forages for grazing and feeding.

This study summarizes animal responses, carcass characteristics, and taste panel evaluations of beef produced under various feeding regimens including grazed range, grazed range and complementary forages and short feedlot finishing.

\section{Prospectus}

First it should be pointed out that about $50 \%$ of the land area in the United States is rangeland, which produces an annual renewable forage resource that comes about without high expenditures of fossil fuels or cultural cnergy. For this reason alone, these lands should receive full use under sustained high levels of production because they represent a valuable food source at reasonable prices.

In addition to the immense area of rangeland in the United States, much of our crop residues could be more effectively used by livestock. Also, most of our low producing croplands could grow complementary forages to supplement rangelands. 
Many forage finishing systems are fashioned from total grazing of range, permanent pastures, or from grazing annual forages such as sorghum, wheat, rye, millet, etc. A combination of selected forages can furnish highly nutritious intake for the animal from birth to slaughter (Bohman et al. 1981, Bowling et al. 1978, Burris et al. 1976, Craig et al. 1959, Dolezal et al. 1981, Harrison et al. 1978, Huffman and Griffey 1975, Shinn et al. 1976, Shupp et al. 1979, Wanderstock and Miller 1948, Williams et al. 1979).

Some pasture finishing systems suggest adding high energy supplements to the grazed forage, especially during the final finishing period (Bidner et al. 1981. Bowling et al. 1978. Burris et al. 1976. Clanton 1977, Coleman et al. 1976, Dougherty et al. 1980, Hunt et al. 1953, Turner and Raleigh 1977, Wanderstock and Miller 1948).

Forage finishing systems also include those practices which use drylot feeding or solely roughages such as silage and chopped hay from various feed sources (Bowling et al. 1977, Cross and Dinius 1978, Harrison et al. 1978, Nelson and Landblom 1978, Oltjen et al. 1971, Wheeling et al. 1975, Young and Kauffman 1978).

Shorter grain feeding periods will occur normally when animals are grown on forages prior to being fed in drylots and when conventional feeding periods are merely shortened because of the need to reduce fleshiness and costs of producing acceptable block beef.

Several studies have shown that beef from cattle finished on all forage rations was of acceptable palatability (Bidner 1975, Bowling et al. 1977, Cross and Dinius 1978, Huffman and Griffey 1975, Nelson and Landblom 1978, Oltjen et al. 1971, Schupp et al. 1979, Wheeling et al. 1975, Young and Kauffman 1978). When carcasses exceed $500 \mathrm{lb}$ and are of similar age and finish, taste panel evaluations could not distinguish between forage- and grain-fed systems (Bidner 1975, Harrison et al. 1978, Huffman and Griffey 1975, Schupp et al. 1979, Young and Kauffman 1978).

Grazing trials that have provided high nutritional forage throughout the growth period of animals show that young steers of Angus, Hereford, or Hereford-Angus crosses can be finished to good quality grades that score desirable by professional taste panels (Bidner et al. 1981, Craig et al. 1959, Harrison et al. 1978, Huffman and Griffey 1975, Schupp et al. 1979).

\section{Procedure}

The research was carried out over a 4-year period on 3 sets of steers in the sandhill range type at the Eastern Colorado Research Center and at the Meats Laboratory on the University campus at Fort Collins, Colo. From a total of 11 feeding regimens studied by Cook et al. $(1980,1981), 3$ were chosen for presentation of the topic to be discussed. However, all of the animals $(220)$ in all 11 treatments were analyzed among frame sizes for presentations herein. The 3 treatments to be discussed were: (1) control group which consisted of animals grazed on native range year-long from birth to slaughter at 18 months of age, (2) animals that grazed native range except during spring when they grazed crested wheatgrass and during the winter and late summer when they grazed forage sorghums, and (3) animals from the native range group that were fed a concentrate ration for 66 days in drylot following the grazing season. Small amounts of supplement were added during winter grazing to correct suspected deficiences of forages especially protein and phosphorus. The supplement was $20 \%$ total protein and was fed at $2.75 \mathrm{lb}$ day.

Animals in treatments 1 and 2 were slaughtered directly off range and forage sorghums in the fall at the time of frost when animals were about 18 months of age. Animals from the feed lot treatment were slaughtered after the 66-day feeding period following grazing on the range to 18 months of age.

Three frame sizes were used in the overall experiment and are referred to as small (3), medium (4), and large (5) because of the 3 rather normal biological types present among the breeds in the study. The biological types of cattle consisted of Hereford, Hereford $X$ Angus, and Exotic $\times$ British cows which were bred to Hereford, Angus, or Simmental bulls. The 3 frame sizes are approximately equivalent to the Missouri frame scores 3,4, and 5 presented by Massey (1979). These were based primarily upon breed, hip height, girth length, and birth and weaning weights adjusted for age and randomly assigned to treatments.

Carcasses were analyzed for cutability, chemical composition, quality, marbling, backfat thickness, palatability traits, yield, and quantity of trimmed primal cuts.

A professionally trained sensory panel evaluated the rib eye steaks for tenderness, juiciness, flavor, and overall satisfaction on an 8 -point hedonic scale $(8=$ very satisfactory, $>4.5=$ acceptable, 1 = very unsatisfactory). Warner-Bratzler shear force values were made on $1.3 \mathrm{~cm}$ core from these steaks after they had cooled to $25^{\circ} \mathrm{C}$. Because of a rather complicated experimental design, the number of animals in the various subclasses varied somehwat because of an effort to use offspring of equal age class distribution in the study. Data were analyzed by least squares analysis for disproportionate subclass numbers (Harvey 1975).

\section{Results and Discussion}

Animal weights at slaughter were 408,429 , and $537 \mathrm{~kg}(916,962$, and $1,203 \mathrm{lb}$ ) respectively for treatments one, two and three.

Table 1. Average daily gains while grazing range and forages and while being ration-fed, along with cold carcass weights for the three treatments and frame sizes.

Forage and/or range grazing

Post weaning

\begin{tabular}{|c|c|c|c|c|c|c|c|c|c|}
\hline & \multirow[b]{2}{*}{ No. animals } & \multirow[b]{2}{*}{$\begin{array}{c}\text { Preweaning } \\
(\mathrm{kg} / \mathrm{da})\end{array}$} & \multicolumn{4}{|c|}{ Post weaning } & & \multirow{2}{*}{ 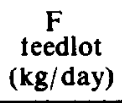 } & \multirow[b]{2}{*}{$\begin{array}{l}\text { Cold carcass } \\
\text { (Wt. kg) }\end{array}$} \\
\hline & & & $\begin{array}{c}\text { Winter }^{d} \\
\text { (kg/day) }\end{array}$ & $\begin{array}{c}\text { Spring }^{\circ} \\
\text { (kg/day) }\end{array}$ & $\begin{array}{l}\text { Summer } \\
\text { (kg/day) }\end{array}$ & $\begin{array}{l}\text { Late summer } \\
\text { (kg/day) }\end{array}$ & $\begin{array}{l}\text { Cold carcass } \\
\text { (Wt. kg) }\end{array}$ & & \\
\hline \multicolumn{10}{|c|}{ Treatment } \\
\hline 1 & 43 & .89 & $.28^{\mathrm{ab}}$ & 1.04 & .89 & $.64^{\mathrm{ab}}$ & $213^{\mathrm{a}}$ & - & - \\
\hline 2 & 36 & .90 & $.35 b$ & .99 & 1.00 & $.73^{\mathrm{b}}$ & - & - & \\
\hline 3 & 19 & .94 & $.24^{\mathrm{a}}$ & 1.02 & 1.04 & $.56^{\mathrm{a}}$ & - & 2.03 & 311 \\
\hline \multicolumn{10}{|l|}{ Frame } \\
\hline 3 & 44 & $.76^{\mathrm{a}}$ & $.26^{\mathrm{a}}$ & $.99^{\mathrm{a}}$ & $.85^{\mathrm{a}}$ & .71 & $202^{\mathrm{a}}$ & $2.02^{\mathrm{a}}$ & $255^{\mathrm{a}}$ \\
\hline 4 & 115 & $.88^{\mathrm{ab}}$ & $.29^{\mathrm{ab}}$ & $.99^{\mathrm{a}}$ & $.96^{\mathrm{ab}}$ & .67 & $217^{b}$ & $1.17^{\mathrm{ab}}$ & $267^{2}$ \\
\hline 5 & 61 & $1.02^{\mathrm{b}}$ & $.33^{\mathrm{b}}$ & $1.08^{b}$ & $1.05^{b}$ & .74 & $246^{\mathrm{c}}$ & $2.20^{\mathrm{b}}$ & $297^{\circ}$ \\
\hline
\end{tabular}

a,b,c Indicates that means among treatments and among frame sizes in the same column are significantly different $(P<.05)$ when superscript letters are different.

Animals in treatments 1 and 3 grazed range and animals in treatment 2 grazed sorghum.

-Animals in treatments 1 and 3 grazed range and animals in treatment 2 grazed crested wheatgrass.

Animals in treatments 1 and 3 grazed range and animals in treatment 2 grazed sorghums.

Number of animals were 22,61 , and 33 for frame size 3 , and 4 and 5 respectively.

Feedlot rations 
Treatment one, which was the range only group, had carcasses grading 50\% Standard, $47 \%$ Good, and $3 \%$ Choice. Carcasses in treatment two, which was the group that received range and complementary grazing from forages, graded 30\% Standard, $67 \%$ Good, and 3\% Choice. Carcasses from treatment three, which were from the group that was fed for 66 days, graded $31 \%$ Standard, $53 \%$ Good, and $16 \%$ Choice. Most of the Standard grade in all treatments were high Standard and most of the Choice grade were low Choice.

Generally, animals that grazed sorghum during winter and late summer (Treatment 2) gained more than animals that grazed range (Treatments 1 and 3) during comparable periods (Table 1).

\section{Carcass Characteristics}

The carcass characteristics are shown in Table 2. Quality grades and marbling scores were not significantly different between the 2 grazing treatments, but animals fed an additional 66 days were significantly higher in both respects. This would be expected since grain-fed animals had more intramuscular fat, which was displayed in higher marbling scores and higher quality grades.

Dressing percentages were highest for the grain fed animals and lowest for the range animals. Rib eye area and quantity of trimmed primal cuts were significantly higher for the animals retained in the feed lot as compared to the 2 groups grazed on forages. This would be expected because of the marked differences in body size between the comparisons. Yield grade was lower (higher cutability) for the animals raised on the range compared to treatments two and three because of the leaner qualities for the grazed animals.

\section{Palatability Evaluations}

In the present study there was no significant difference $(P<.05)$ between the 2 groups that grazed forage for either amount of marbling, backfat thickness, or percent longissimus muscle fat, but the group fed 66 days on concentrates were significantly higher in all 3 cases. The amount of marbling was $2.41,2.52$, and 2.92, respectively, for the 3 treatments. The average backfat thickness was $0.36,0.43$, and $0.79 \mathrm{~cm}(0.16,0.18$, and 0.32 inches $)$ and the average percent muscle fat was $2.4,2.4$, and 4.3 , respectively, for range, range-forage, and 66-day fed animals (Table 2). This might imply that neither of the forage fed groups actually produced acceptable meat, but taste panel evaluations showed otherwise (Table 3). There were no significant differences $(P<.05)$ in palatability traits (tenderness, flavor, juiciness) among the 3 treatment groups. All differences in organoleptic scores among trcatments were small and all average scores were above 4.5 , which is the mid-point of the scoring range and is considered acceptable from the viewpoint of palatability traits. Only juiciness and overall acceptability scores were below 5 but even in these cases they all round off to 5 . If the carcasses below high Standard are eliminated, the taste panel scores for all palatability traits for all treatments are

\section{increased somewhat.}

It is thus shown that average carcasses from all 3 treatments met palatability standards based upon professional taste panel scores to meet evaluations for acceptable meat. It is shown, however, in Table 3 that organoleptic traits (tenderness, flavor, and juiciness) are higher for the grain fed animals than for the animals raised and finished on grazed range and complementary forages. This means that grain-fed animals are more palatable, but the average rating for meats from forage fed animals were still acceptable for block beef. Eight. percent of the carcasses in standard grade were rated desirable $(>4.5)$ with about $70 \%$ of the carcasses being a high Standard. Likewise, about $84 \%$ of the carcasses in Good grade were rated desirable $(>4.5)$ with about equal distribution of carcasses in low, medium, and high Good. Approximately $88 \%$ of the carcasses in Choice grade were scored desirable $(>4.5)$ with $77 \%$ of them in the low Choice category.

Lower quality grades tend to have lower palatability scores and likewise lower probability of furnishing carcasses that score acceptable for block beef. Production costs, however, are being lost because under conventional methods it is impossible to precisely differentiate between the $80 \%$ of the carcasses in high Standard and Good grades that are acceptable from those that are unacceptable from the standpoint of palatability traits. This results in large numbers of acceptable carcasses being placed in low quality grades generally used for manufactured meats rather than block meat.

\section{Lower Thresholds for Block Meat Evaluation}

It is realized that lower thresholds are established for the sake of presenting a high probability of the meat meeting desirable palatability traits, but it neglects the option of including a high percentage of the meat that may be lower quality grade yet acceptable as primal cuts. These carcasses might feasibly be an economy grade for many people. In any case, such meat deserves more than being used for manufactured products. Indications are that consumers will purchase such meats if given the opportunity and will return for more because of lower price, leaner meat characteristics, and suitability to individual tastes (Schupp et al. 1979).

Amount of backfat thickness and percent lipid (percent fat in the longissimus muscle) have been suggested as lower thresholds for identifying acceptable beef from unacceptable beef by Tatum et al. (1982) and Campion et al. (1975) respectively. Tatum et al. (1982) suggested as the lower limit a backfat thickness of $0.76 \mathrm{~cm}(0.3$ inch) and Campion et al. (1975) suggested $2.9 \%$ intramuscular fat as the lower limit for segregating desirable from undesirable beef in young animals less than $\mathbf{3 0}$ months of age.

In recent study by Cramer et al. (1984), it was shown that if backfat thickness of $0.76 \mathrm{~cm}(0.3 \mathrm{inch})$ were accepted as the lower threshold of desirability, only $13 \%$ of the total carcasses in Choice grade would be rejected, but in the Good grade $53 \%$ would be

Table 2. Means for carcass characteristics by treatment and frame size.

\begin{tabular}{|c|c|c|c|c|c|c|c|c|c|}
\hline Item & $\begin{array}{c}\text { Number } \\
\text { of } \\
\text { carcasses }\end{array}$ & $\begin{array}{l}\text { USDA }^{\mathbf{d}} \\
\text { quality } \\
\text { grade }\end{array}$ & $\begin{array}{c}\text { Marbling } \\
\text { amount }\end{array}$ & $\begin{array}{l}\text { Dressing } \\
\text { percent }\end{array}$ & $\begin{array}{l}\text { USDA }^{f} \\
\text { yield } \\
\text { grade }\end{array}$ & $\begin{array}{c}\text { Rib eye } \\
\text { area } \\
\left(\mathrm{cm}^{2}\right)\end{array}$ & $\begin{array}{l}\text { Adjusted fat } \\
\text { thickness } \\
\text { (cm) }\end{array}$ & $\begin{array}{l}\text { Trimmed } \\
\text { primals } \\
(\mathrm{kg})\end{array}$ & $\begin{array}{l}\text { Intra- } \\
\text { muscle fat } \\
(\%)\end{array}$ \\
\hline \multicolumn{10}{|c|}{ Treatment } \\
\hline 1 & 43 & $6.67^{a}$ & $2.41^{\mathrm{a}}$ & $54.0^{\mathrm{a}}$ & $1.80^{\circ}$ & $63.2^{\mathrm{a}}$ & $0.36^{\mathrm{a}}$ & $144^{a}$ & $2.42^{a}$ \\
\hline 2 & 36 & $7.14^{b}$ & $2.52^{\mathrm{a}}$ & $56.4^{b}$ & $1.96^{\mathrm{b}}$ & $65.8^{\mathrm{a}}$ & $0.43^{\mathrm{a}}$ & $125^{\mathrm{b}}$ & $2.44^{a}$ \\
\hline 3 & 19 & $7.47^{\mathrm{b}}$ & $2.92^{b}$ & $58.6^{\mathrm{c}}$ & $2.06^{\mathrm{b}}$ & $85.2^{\mathrm{b}}$ & $0.79^{\mathrm{b}}$ & $160^{c}$ & $4.35^{b}$ \\
\hline \multicolumn{10}{|c|}{ Frame $^{h}$} \\
\hline 3 & 44 & $7.82^{\mathrm{a}}$ & $2.84^{\mathrm{a}}$ & 56.6 & $2.48^{a}$ & $67.7^{\mathrm{a}}$ & $0.84^{a}$ & $132^{\mathrm{a}}$ & 3.36 \\
\hline 4 & 115 & $7.75^{\mathrm{a}}$ & $2.88^{\mathrm{a}}$ & 57.3 & $2.27^{\mathrm{a}}$ & $71.6^{\mathrm{a}}$ & $0.74^{a}$ & $134^{\mathrm{a}}$ & 3.30 \\
\hline 5 & 61 & $7.08^{b}$ & $2.66^{\mathrm{b}}$ & 57.2 & $1.93^{\mathrm{b}}$ & $80.6^{b}$ & $0.58^{\mathrm{b}}$ & $155^{\mathrm{b}}$ & 3.24 \\
\hline
\end{tabular}

\footnotetext{
$a, b, c$ Means within a main effect and in the same column bearing different superscript letters are significantly different $(P<.05)$.

${ }_{10}=$ low choice; $7=$ low good, $4=$ low standard.

4 = small; $3=$ slight; $2=$ traces.

Carcass with Yield Grade I would have $>52.3 \%$ trimmed retail cuts and Yield Grade 5 would have $<45.4 \%$ trimmed retail cuts.

Fat measurement taken over the longissimus muscle at the 12 th rib, then adjusted for unusual fat deposition over the carcass.

hodified Missouri frame score for 220 animals included in 11 treatments studied by Cook et al. (1980, 1981).
} 
Table 3. Means for taste panel evaluation and Warner-Bratzler shear force values on ribs steaks by treatment and frame size.

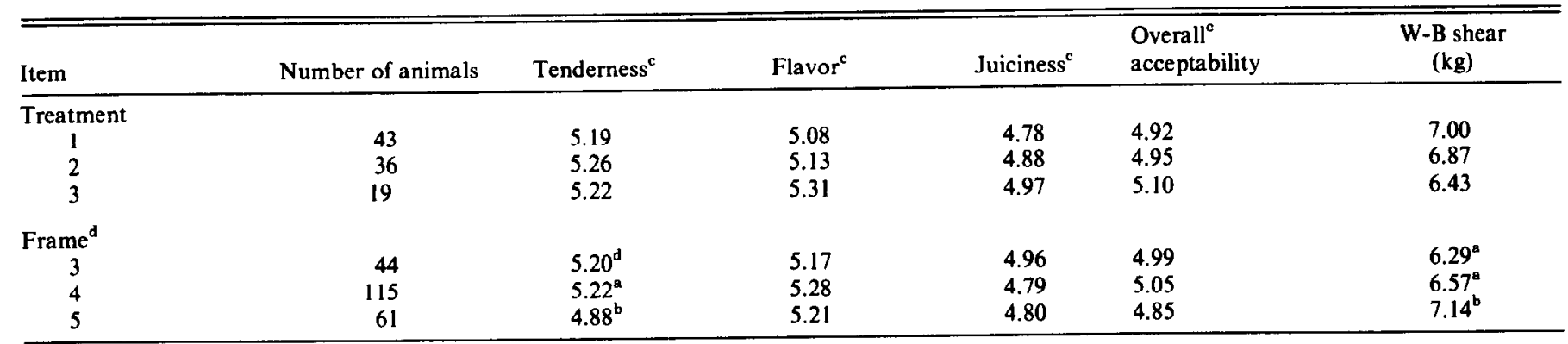

\footnotetext{
abans within a main effect and in the same column bearing different superscript letters are significantly different $(P<.05)$.

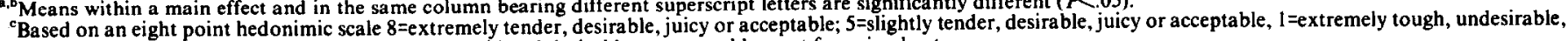
dry or unacceptable). Scores of 4.5 or above are considered desirable or acceptable meat for primal cuts.

Modified Missouri frame score for 220 animals included in 11 treatments studied by Cook et al. (1980, 1981).
}

rejected. If $2.9 \%$ intramuscular fat is used as the lower threshold of acceptability, $16 \%$ would be rejected from Choice grade, but in Good grade $41 \%$ would be rejected. Under conventional methods of chilling, the study by Cramer et al. (1984) indicates that both thresholds for backfat thickness and percent intramuscular fat were perhaps too high to include most of the acceptable meat in both Good and high Standard grades.

The present study shows that both range and range along with complementary forages can produce acceptable meat. It may grade lower and it may score lower in taste panel evaluations, but it is indeed acceptable and would be purchased by consumers at an advantageous price even though the probability of receiving an unacceptable steak is somewhat higher (about $10 \%$ ) compared to grain fed steaks of Choice grade. Huffman and Griffey (1975) state that "anyone who says pasture beef must be poor in quality is simply misinformed. Meat from cattle finished on high quality winter grazing can be equal to that from comparable cattle getting a 90-day feedlot finishing period after grazing."

Breidenstein et al. (1968) and Henrickson and Moore (1965) found that the degree of marbling in the muscle beyond, perhaps, a trace was of little importance in young beef animals. Data in the present study would tend to agree that young animals 18 to 24 months of age place a high percentage of carcasses in desirable meat categories with only a trace of intramuscular fat.

\section{Frame Size and Animal Response}

In the present study large-frame animals gained slightly more than small-frame animals (Table 1), but small-frame animals had higher finish at comparable ages and period of feeding. In other studies large-frame animals also made substantially higher daily gains but not always with higher quality meat grades (Koch et al. 1976, 1977; Prior et al. 1976, 1977; Smith et al. 1980). In another study Laster et al. (1976) found that small-frame cattle reached pubcrty at an carlicr age than large-frame cattlc. Koch ct al. (1976), Smith et al. (1977) and Prior et al. (1977) found that small-frame cattle fattened faster and reached a particular quality grade sooner than large-frame cattle.

Animals in treatments one and two that were finished on range and range along with complementary forages, respectively, had 42, 47 , and $11 \%$ in Standard, Good, and Choice grades for the smallframe animals and 58, 42, and 0\% in Standard, Good, and Choice grades, respectively, for large-frame animals. Thus the smaller frame animals tended to finish more rapidly on forages and have higher quality grades than larger-frame animals.

Steers that were fed for an additional 66 days also had a larger number of the small-frame animals grading Good and Choice than the large-frame animals. The average for all 220 animals in all treatments in the original study (Cook et al. 1980, 1981) showed that animals in the small-frame sizes graded 0.74 of a point higher than larger-frame animals. Steers in frame sizes 3 and 4 graded average Good to high Good compared to an average low Good for the frame-size 5 steers. Bohman et al. (1981) stated that British breeds (Hereford and Angus) fatten earlier at lighter weights with limited grain and hence have a greater probability of producing acceptable beef on pasture and roughage than the bigger exotic breeds.

Although not presented in tabular form in this paper, smallframe cattle (frame-size 3) in addition to having greater backfat thickness and more intramuscular fat, also had more separable fat and less separable lean and bone than large-frame steers at the same age. This would be expected since the small-frame animals generally had higher finish indexes than the large-frame animals at any comparable age or time on the trials.

Tenderness and shear force measurements were affected by frame size (Table 3). Rib steaks from frame-sizes 3 and 4 steers were slightly more tender $(P<.05)$ and required less shear force $(P<.05)$ compared to steaks from frame-size 5.

\section{Summary and Conclusions}

From 1976 to 1981, 3 annual sets of steer calves were raised from birth to slaughter. Three treatments were involved, namely: (1) raised entirely on range to 18 months of age; (2) raised on range and complementary forages to 18 months of age; and (3) raised on range to 18 months of age and fed subsequently for 66 days. Animals in the study were of crosses with Hereford, Angus, and exotic breeds; thus steers that were slaughtered were of the general frame sizes (small, medium, and large).

Carcass characteristics and organoleptic traits were measured and compared by treatments and frame sizes. Quality grade, marbling score, rib eye area, fat thickness, and percent intramuscular lipid were significantly higher for the animals receiving grain at the end of the grazing period than for the 2 grazing groups.

There were no significant differences in palatability traits (tenderness, flavor, and juiciness) among the grazing cattle and those that were finished on grain for 66 days. About $80 \%$ of the carcasses in each of the 3 treatments were scored acceptable by the taste panel. Neither backfat thickness of $0.76 \mathrm{~cm}(0.3 \mathrm{inch})$ or percent intramuscular fat at $2.9 \%$ appeared adequate as a lower threshold to identify unacceptable carcasses within any of the 3 treatments because they caused a high number of acceptable carcasses to be used in manufactured meats at a loss to the producers.

Small-frame animals gained less per day but had higher finish at comparable ages and period on treatments than large-frame animals. Carcasss of small-frame animals had significantly more intramuscular fat, more separable fat, and less separable lean than large-frame animals. Tenderness and shear force measurements were significantly more favorable for small-frame animals than large-frame animals when measured over all forage and concentrate feeding trials.

An economy grade of beef featuring pasture and range finished animals for moderate income people at prices commensurate with 
lowered costs of production should receive consideration by the beef industry. Choice grade beef with a probability of 1 out of 10 steaks being slightly unacceptable compared to a Good grade or high Standard grade meat at a probability of 2 out of 10 steaks being slightly unacceptable should have a financial advantage to both the consumer and the producer.

It was concluded that the use of small-frame cattle could enhance the use of more pasture and forages because they mature more rapidly and finish at a younger age than large-frame cattle. This allows grazing to contribute more to finishing beef animals either through finishing directly on pasturage, or through forages along with shorter drylot feeding periods.

It was further concluded that acceptable beef could be produced directly from range if calves were kept on a growing diet of nutritious forages with minimum supplement until they were 18 months of age. Steers raised by grazing on the range and complementary forages such as crested wheatgrass and forage sorghums without grain can produce acceptable beef of a higher quality grade than steers grazing only native range. Animals fed 66 days following grazing produced palatable beef comparable to animals that had only native range along with the complementary forages.

It is apparent that future beef production will rely more on range and forages to produce block beef because of the anticipated higher prices for grain and the trend for consumers to purchase leaner meat.

\section{Literature Cited}

Bidner, T.D. 1975. A comparison of forage-finished and grain-finished beef. Proc. Recip. Meat Conf. 29:301.

Bidner, T.D., A.R. Schupp, R.E. Montgomery, and H.C. Carpenter. 1981. Acceptability of beef finished on all-forage, forage-plus-grain or high energy diets. J. Anim. Sci. 53:1181.

Bohman, V.R., E.H. Jensen, T.P. Ringkob, and R.E. Eckert. 1981. Forage finishing of beef cattle. Nevada Agr. Exp. Sta. Bull. B-49.

Bowling, R.A., G.C. Smith, Z.L. Carpenter, T.R. Dutson, and W.M. Oliver. 1977. Comparison of forage-finished and grain-finished beef carcasses. J. Anim. Sci. 45:209-215.

Bowling, R.A., J.K. Riggs, G.C. Smith, Z.L. Carpenter, R.L. Reddish, and O.D. Butler. 1978. Production, carcass and palatability characteristics of steers produced by different management systems. J. Anim. Sci. 46:333-340.

Bowling, R.A., G.C. Smith, Z.L. Carpenter, and T.R. Dutson. 1981. Comparison of carcass, characteristics and sensory evaluations of forage- and grain-finished beef of identical grade. Beef Cattle Research in Texas. P.R.-3619.

Breidenstein, B.B., C.C. Cooper, R.G. Cassens, G. Evans, and R.W. Bray. 1968. Influence of marbling and maturity on the palatability of beef muscle. 1. Chemical and organoleptic considerations. J. Anim. Sci. 27:1532.

Burris, W. Roy. 1976. Finishing steers on ryegrass-clover pasture with supplemental grain. Mississippi Agr. Exp. Sta. Bull. 839.

Campion, D.R., J.D. Crouse, and M.E. Dikeman. 1975. Predictive value of USDA beef quality grade factors for cooked meat palatability. J. Food Science 40:1225.

Clanton, D.C. 1977. Finishing cattle on pasture and other forages: Irrigated pasture. J. Anim. Sci. 44:908.

Coleman, S.W., F.M. Paste, and D.W. Beardsley. 1976. Effect of level of supplemental energy fed grazing steers on performance during the pasture and subsequent dry lot period. J. Anim. Sci. 42:27.

Cook, C. Wayne, J.W. Walker, Mark H. Ebberts, Larry R. Rittenhouse, E.T. Bartlett, David A. Cramer, Peter T. Fagerlin, and Mark C. McKewn. 1980. Alternate red meat production systems. Progr. Rep. Contract No. AER 77-04098. National Science Foundation.

Cook, C. Wayne, J.W. Walker, Mark H. Ebberts, Larry R. Rittenhouse, E.T. Bartlett, David A. Cramer, Peter T. Fagerlin, and Mark C. McKean. 1981. Alternate red meat production systems. Progr. Rep. Contract No. AER 77-04098. National Science Foundation.

Craig, H.B., T.N. Blumer, and E.R. Barrick. 1959. Effect of several combinations of grass and grain in the ration of beef steers on the color characteristics of lean and fat. J. Anim. Sci. 18:241

Cramer, David A., C. Wayne Cook, and Larry R. Rittenhouse. 1984. Meat characteristics and palatability traits for range, forage and grain fed animals. J. Anim. Sci. (At Press). ross, H.R., and D.A. Dinius. 1978. Carcass and palatability characteristics of beef steers finished on forage diets. J. Anim. Sci, 47:1267.

Daugherty, D.A., H.A. Turner, W.H. Kennick, E.A. Elgasim, and R.J. Raleigh. 1980. Range vs. feedlot finishing. 1. Performance and carcass quality of fall born steers finished on forage with limited grain. Proc. West Sec. Amer. Soc. Animal. Sci. 31:139.

Dolezal, H.G., G.C. Smith, J.W. Savell, and Z.L. Carpenter. 1981. Timeon-feed effects on carcass and palatability characteristics of steers and heifers. Beef Cattle Research in Texas. P.R.-3814.

Harrison, A.R., M.E. Smith, D.M. Allen, M.C. Hunt, C.L. Kastner, and D.H. Kropf. 1978. Nutritional regime effects on quality and yield characteristics of beef. J. Anim. Sci. 47:383-388.

Harvey, W.R. 1975. Least-squares analysis of data with unequal subclass numbers. USDA Agr. Res. Serv. ARS A-4.

Henrickson, R.L., and R.E. Moore. 1965. Effects of animal age on the palatability of beef. Oklahoma Agr. Exp. Sta. Tech. Bull. T-115.

Huffman, D.L., and W. Griffey. 1975. Cattle finished on winter pasture rate high in carcass quality. Highlights Agr. Res., Ala. Agr. Exp. Sta. $22: 3$.

Hunt, R.E., C.M. Kincaid, and R.C. Carter. 1953. Grain on grass-fattened cattle? Virginia Agr. Exp. Sta. Bull. 458.

Koch, R.M., and M.E. Dikeman. 1977. Characterization of biological types of cattle. V. Carcass wholesale cut composition. J. Anim. Sci. 45:30.

Koch, R.M., M.E. Dikeman, D.M. Allen, M. May, J.D. Crouse and D.R. Campion. 1976. Characterization of biological types of cattle: III. Carcass composition, quality and palatability. J. Anim. Sci. 43:48.

Laster, D.B., Gerald M. Smith and Keith E. Gregory. 1976. Characterization of biological types of cattle. IV. Postweaning growth and puberty of heifers. J. Anim. Sci. 43:63.

Massey, J.W. 1979. On the farm performance testing. Missouri Beef Cattle Improvement Programs, Univ. Missouri-Columbia M P474.

Nelson, James L., and Doug L. Landblom. 1978. Grass fed beef, North Dakota Farm Res. 36:6.

Oltjen, R.R., T.S. Rumsey and P.A. Putnam. 1971. All forage diets for finishing beef cattle. J. Anim. Sci. 32:327.

Prior, Ronald L., Ronald H. Kohlmeier, Larry V. Dundiff, Michael E. Dikeman and John D. Crouse. 1976. Type tells in the feedlot. USDA Agr. Res. November.

Prior, R.L., R.H. Kohlmeier, L.V. Cundiff, M.E. Dikeman and J.D. Crouse. 1977. Influence of dietary energy and protein on growth and carcass composition in different biological types of cattle. J. Anim. Sci. 45:132.

Schupp, Alvin, Thomas Bidner, William McKnight, David Smith, John Carpenter, Jr., and Fred Wiegmann. 1979. Acceptance of beef finished on forages or with limited grain. La. Agr. Exp. Sta. Bull. 714.

Shinn, Jerry, Charles Wlasten, J.L. Clark, G.B. Thompson, H.G. Hedrick, W.C. Stringer, A.G. Matches and J.V. Rhodes. 1976. (Abstract). Effect of pasture and length of grain feeding on characteristics of beef. J. Anim. Sci. 42:1367.

Smith, G.M., D.B. Laster, L.V. Cundiff, and K.E. Gretory. 1976. Characterization of biological types of cattle. II. Postweaning growth and feed efficiency of steers. J. Anim. Sci. 43:37.

Smith, G.M., J.D. Crouse, R.W. Madigo, and K.L. Neer. 1977. Influence of feeding regimen and biological type on growth and paltability of steers. J. Anim. Sci. 45:236.

Smith, Gary, Zerle Carpenter, Jeff Savell and Charley Murphy. 1980. Size and muscling effects on cattle. Texas Agr. Exp. Sta. Brief Reports on Agr. Res. in Texas. Vol. 6, No. 11.

Tatum, J.D., G.C. Smith and Z.L. Carpenter. 1982. Interrelationships between marbling, subcutaneous fat thickness and cooked beef palatability. J. Anim. Sci. 54:777.

Turner, H.A. and R.J. Raleigh. 1977. Production of slaughter steers from forages in the arid west. J. Anim. Sci. 44:901.

Wagner, Don and Floyd Horn. 1976. Greater emphasis on forage in finishing programs. Okla. Agr. Exp. Sta. Res. Rep. P-742:41-42.

Wanderstock, J.J. and J.I. Miller. 1948. Quality and palatability of beef as affected by method of feeding and carcass grade. Food Research 13:291-303.

Wheeling, R.R., B.W. Berg and J.A. Carpenter, Jr. 1975. Effects of breed and forage vs. grain feeding on beef palatability. J. Anim. Sci. 41:305.

Williams, J., D.G. Wagner, L.E. Walters, J.J. Guenther, G.H. Horn, and G. Waller. 1979. Characteristics of forage-fed vs grain-fed slaughter cattle. Okla. Agr. Exp. Sta. Res. Rep. MP-104.

Young, A.W. and R.G. Kauffman. 1978. Evaluation of beef from steers fed grain, corn silage or haylage-silage diets. J. Anim. Sci. 46:41. 